\title{
Synergies in subject parallels: Coteaching "music-drama"
}

\author{
MARIE-HELENE ZIMMERMAN NILSSON ${ }^{1^{*}}$ (1) and COLETTE MURPHY ${ }^{2}$ \\ ${ }^{1}$ University West, Trollhattan, Sweden \\ 2 Trinity College, Dublin, Ireland
}

\section{RESEARCH PAPER}

Received: August 6, 2020 • Accepted: February 17, 2021

Published online: April 10, 2021

(C) 2021 The Author(s)

\begin{abstract}
This case study contributes with a new coteaching design, in which experienced teachers from two different aesthetic subjects are planning, teaching and evaluating together in higher education, more specifically in general preschool teacher education. The aim of the study is to analyse how two drama teachers and a music teacher reflect on their coteaching. Coteaching, when teachers teach together with shared responsibility to meet their students' learning needs, is a pedagogical approach to enable an active learning process. Research and practice in coteaching have emerged, mostly designed with coteachers within the same subject. However, more research is needed about teachers from different subjects coteaching together. The theoretical framework is sociocultural, with special emphasis on aspects of learning from 'the other' in praxis by working in a zone of proximal development (ZPD). Analysed data consist of field notes and audio-recorded teacher group conversations. Main findings show synergies in subject parallels, based on the analysis of coteachers' reflections as learning processes within their ZPD. In conclusion, a major contribution in terms of synergy in coteaching appears in subject parallels related to specific subject matter concepts, where music and drama are intertwined in the classroom as "music-drama", as a new dimension.
\end{abstract}

\section{KEYWORDS}

teacher education, aesthetic subjects, coteaching, synergies, case study

\footnotetext{
*Corresponding author. E-mail: marie-helene.zimmerman-nilsson@hv.se
} 


\section{INTRODUCTION}

Over the last 20 years, research and practice in coteaching have emerged, mostly designed with coteachers within the same subject. Coteaching implies sharing of the expertise between teachers, that expands opportunities for students to learn (Murphy \& Martin, 2015). Coteaching differs from the hyphenated concept co-teaching that is primarily used in special education, and other concepts such as team teaching and collaborative teaching. Among these approaches, coteaching specifically requires collective planning, practice and reflection, constituting pedagogy that enables development and improvement of teaching (Murphy \& Martin, 2015). Hence, coteaching is an arrangement in which at least two teachers plan, teach and assess to improve conditions for learning for their students and for their ability to teach (Roth \& Tobin, 2005). The coteachers are "sharing responsibility for meeting the learning needs of students and, at the same time, learning from each other" (Murphy \& Martin, 2015, p. 277). There are several ways of designing coteaching partnerships. For instance, the coteachers may be student teachers, class teachers, student teacher and class teacher together or in combination with university teachers (Murphy \& Carlisle, 2008; Roth \& Tobin, 2005; Scantlebury, Gallo-Fox, \& Wassell, 2008).

Problematic issues have been identified and acknowledged by different researchers. Aspects that can affect coteaching negatively are lack of time for coteachers to reach a shared understanding of the collaboration (Guise, Habib, Thiessen, \& Robbins, 2017), to establishing individual and joint roles (Murphy, Carlisle, \& Beggs, 2009), and to deal with difficulties when they occur, especially at the beginning of collaboration (Scantlebury et al., 2008). Further, the lack of paying attention to the connection between relations of power and coteaching has been critically discussed (Kadri \& Salles, 2019; McClure \& Cahnmann-Taylor, 2010; Murphy et al., 2009). Furthermore, structural problems have been addressed, given that coteaching often is implemented top-down in the school organization which disregards the perspective of the coteacher (McClure \& Cahnmann-Taylor, 2010).

Coteaching in higher education has been described as a collaboration within the same subject with potential to allow for synergy in the classroom, as a method to better meet student needs and as a way to develop a reflective practice (Buczynski \& Sisserson, 2008; Chu, 2006; Ferguson \& Wilson, 2011; Murphy \& Martin, 2015). Further, coteaching between pre-service teachers and in-service teachers in a subject has been shown to reduce the gap between theory and practice (Murphy \& Martin, 2015; Roth, Masciotra, \& Boyd, 1999). The purpose of coteaching in teacher education is to make a closer connection between theory and practice, to enhance reflective classroom practice and to develop the pedagogical content knowledge of teachers (Murphy \& Martin, 2015). Moreover, when coteachers share different qualities and knowledge, an arena for a more democratic and less hierarchical teaching can be established. Thus, collective learning is emphasized together with enhanced possibilities for classroom actions and change. However, it is essential to inform and prepare the teachers before coteaching together in higher educational contexts (Locke et al., 2017).

As research and practice in coteaching have mostly been designed with coteachers within the same subject, there is a need for research about teachers from different subjects coteaching together. Therefore, this case study contributes with a new design, having experienced teachers from two different aesthetic subjects, music and drama, planning, teaching and evaluating together in higher education, more specifically, in preschool teacher education. Further, as coteaching often implies one experienced teacher teaching together with a pre-service teacher 
(Murphy \& Martin, 2015; Roth et al., 1999), this study is also new in its design where three experienced teachers from two different subjects teach together in the classroom. As such, the drama teachers are less experienced in music than the music teacher and the music teacher is less experienced in drama than the drama teachers, but all three have studied the other subject during their education and use it in their ordinary teaching. This forms the platform for an arena of learning from each other, as the teacher educators can guide one another and gain new knowledge and skills. The research context is an aesthetic methods course, where a coteaching period was planned with the ambition to achieve a more holistic approach, to increase student learning and better relate to their future profession as preschool teachers. The aim of the study is to analyse how two drama teachers and a music teacher reflect on their coteaching.

\section{Literature review}

In coteaching studies, aspects of synergies have been addressed in different ways. Coteaching in higher education has been described as a collaboration that has a potential to allow for synergy in the classroom and as a method to better meet student needs (Ferguson \& Wilson, 2011). Here, two professors with the same subject expertise acted as coteachers in an undergraduate reading methods course. The professors changed their understanding of coteaching related to power and availability of teacher expertise, from being competitive with one another, to gaining from each others' teaching competencies with an emphasis on meeting student needs. Similarly, coteaching has been described as an arena for differentiated instruction, that could provide positive synergy to enhance student learning (Chu, 2006). Coteaching between teachers and university professors has been focused in order to achieve instructional synergy (Buczynski \& Sisserson, 2008). The coteachers came to realise that the different cultures, represented by the university and the district overlapped, and that this assisted them to become better professional educators. Thus, the instructional synergy of the coteaching was enhanced. Furthermore, structured collaborative planning for coteachers in inclusive classrooms has been studied (Embury \& Dinnesen, 2013). It is assumed that two teachers coteaching could create educational synergy and positive changes related to student learning (Embury \& Dinnesen, 2013). Their findings show that when coteachers regularly planned together, both changes in teaching behaviours and roles appeared in their descriptions. These changes indicated a higher degree of participation between coteachers, more creativity in planning lessons and a clearer emphasis on a shared classroom.

In a study of coteaching in music teacher education, undergraduate music pre-service teachers (PST) cotaught with primary school teachers under an 8-week school placement (Kerin \& Murphy, 2015). The PSTs gained teacher professional agency in content knowledge, pedagogical knowledge, curricular knowledge and pedagogical content knowledge. Hence, they gained more confidence in their own musicianship and generated new subject knowledge by creating and composing music for the classroom. They also developed their ability to critically assess their own planning and the understanding of the music curriculum in collaboration with experienced teachers and came to realise that the child's needs and learning experiences is at the center of teaching. There was also a significant improvement in professional agency development among the students in comparison to the traditional school placement. In Artistic education in higher education, a coteaching setting was staged in a music analysis course (Vlahopol, 
2018). Coteaching was used to bring together practical and theoretical parts of the student musicians in a way that correlates with different aspects of content, such as harmony, counter point, aesthetics and music theory. The coteaching in the course helped students to create an understanding of an educational process characterised by mutual support and diversity, where collaboration and professionalism constituted core elements. This contributed in the students' development towards the complete musician.

In language-drama teaching classrooms, Chu (2006), suggests that a story-performing task could be a coteaching arena, with one drama teacher and one teacher in writing. In smaller groups, the students could learn at the drama skill station and at the story writing station, where both teachers could use their competencies in order to meet student needs. To enhance teacher professional development, a researcher-teacher coteaching project in drama was accomplished (Stinson, 2009). A changing practice occurred where the importance of students' engagement was put to the fore and where many teachers described benefits in including drama in their teaching due to improved student outcomes in the classroom. A challenge was to emphasise drama as processes of collaboration and not as activities where talent was a prerequisite.

In the present study, the design of having teachers from different subjects coteaching together, differ from studies focussing on coteachers in the same subject and synergies that occur in such settings. It also differs from studies of coteaching in music education and drama education respectively, as music and drama teachers are coteaching together. As such, the present study has the potential to discover new aspects of coteaching, appearing in the cooperation between teachers in two different aesthetic subjects.

\section{RESEARCH QUESTION}

The research question of the study is: What are the perspectives of two drama and one music teacher on the impact of coteaching in these two subjects?

\section{METHODS}

Teacher educators within teacher educations ought to provide PSTs with resources that function as tools for creating meaningful social interaction within pedagogical practices. From such a perspective, this study emanates from sociocultural perspectives on learning. The theoretical framework emphasises the collective character of learning and teaching (Vygotsky, 1978). Levykh (2008) highlights Vygotsky's emphasis on both intellect and affect related to learning and development, being closely linked to one another. Such a social beginning of the learners' learning and development can be represented by the zone of proximal development (ZPD). The ZPD implies the distance between independent learning and the potential development in learning with assistance of more capable peers, indicating that the collective achieve more than the individual (Levykh, 2008; Vygotsky, 1978; Wertch, 1984). ZPD is understood as a reciprocal learning process where the persons learn by interacting with each other (Tudge \& Scrimsher, 2003). As such, ZPD represents a cultural process, characterised by collaboration and cooperation, a process that also encompasses affective connections between the persons included herein (Levykh, 2008). 
The collective character of teaching and learning is defined within sociocultural approaches of coteaching (Murphy \& Carlisle, 2008). Coteaching is described as a framework where coteachers develop collectively by sharing expertise and showing mutual respect, based on sociocultural perspectives on learning (Murphy, Scantlebury, \& Milne, 2015). In coteaching, ZPD can be understood as the discrepancy between the learning a teacher educator can achieve unaided, compared with the learning attained with assistance from another teacher (Murphy et al., 2015). This process implies collaborative production in interaction among the participants (Van Oers, 2007). Hence, coteaching can be characterised as a ZPD, where collective teaching and learning can lead to developed joint actions with the potential to become a part of the teaching practice and of coteachers' actions, emanating from planning, teaching and evaluating together. More specifically, in this paper, ZPD is applied from a cultural historical activity theory perspective (CHAT), as "a conceptual tool to help understand the complexities involved in the activity of coteaching, as coteachers engage in meaning making processes and interact with each other, the students and the school environment" (Murphy et al., 2015, p. 284).

The context for the current research was an 18-week university aesthetic methods course, comprising music, drama, dance and visual arts, during the third year of a three and a half-year general preschool teacher education program in higher education. The pre-service teachers are studying to become preschool teachers and will teach children from one to five years of age. During the course, the pre-service teachers (PSTs) attended practical workshops in music and drama respectively. The distance between these two subjects was criticized by the PSTs and questioned by the teachers. In order to achieve a more holistic approach and to learn from one another, coteaching in music and drama was initiated. Hence, the collaboration was not topdown implemented (McClure \& Cahnmann-Taylor, 2010), but emanated from the teaching practice. The coteaching period included co-planning, coteaching and co-evaluation (Murphy \& Martin, 2015). At the beginning of the period, the teachers met and planned their coteaching. At this meeting, they both made a written plan and engaged in practical training when they tried out ways to collaborate. As such, the design acknowledges the need to inform and prepare teachers (Locke et al., 2017) and enable them to establish individual and joint roles (Murphy et al., 2009), given that considerable time was spent on discussions and planning at the beginning of collaboration. Second, the teachers cotaught a class with preschool student teachers, during three two-hour lessons. Third, the teachers met to evaluate their coteaching. Data derives from field notes of teacher reflections, audio-recorded teacher group conversations and complementary written student reflections. Here, field notes and transcribed reflections from audio-recorded teacher group conversations were analysed. As this paper focuses on coteaching enactment between the teachers, the written student reflections will be analysed in another paper.

The phases of the study are summarized in the following Table 1:

Teachers and pre-service teachers (PSTs) all agreed to participate in the study. Their participation was voluntary and the study was not part of any student course assessment. The teachers in the study are well experienced teacher educators in drama and music respectively in teacher education. Therefore, the design differs from coteaching with one experienced and one less experienced teacher, where relations of power have been inadequately addressed (Kadri \& Salles, 2019; McClure \& Cahnmann-Taylor, 2010; Murphy et al., 2009). The teachers and the PSTs were informed orally about the study's aim, time schedule, how the materials would be 
Table 1. Phases of the study

\begin{tabular}{|c|c|c|}
\hline Study phase & Activities & Data and collection strategies \\
\hline One & $\begin{array}{c}\text { Teachers }{ }^{\mathrm{a}} \text { co-planning lessons in } \\
\text { "music-drama" }\end{array}$ & Audio recording \\
\hline Two & Teachers coteaching "music-drama" & $\begin{array}{l}\text { Field notes of teacher reflections } \\
\text { Written student reflections }\end{array}$ \\
\hline Three & $\begin{array}{c}\text { Teachers evaluating their coteaching } \\
\text { period }\end{array}$ & Audio recording \\
\hline
\end{tabular}

a Two drama teachers and a music teacher.

stored, presented and published, as well as who to contact concerning any questions about the research project. All participants have been given fictitious names.

As the study focuses on three teachers during an aesthetic methods course, a qualitative case study methodology was used. By using such an approach, the case is studied within the teachers' real life professional context (Yin, 2009). A qualitative analysis was conducted through content analysis (Graneheim \& Lundman, 2004). The analysis was based on the patterns derived from data during the coteaching period.

In the analysis, the material was initially read several times which led to an overall content picture of the material. The focus in the teachers' reflections was described in accordance with their main content and sorted into content groups. To assess the reliability of the coding, the same coding was used, and the same material was re-analysed one week later. Final patterns, consisting of four themes indicating the main thrust of the data material were decided. The selection of sequences to be presented in the paper was then made, based on the criterion that they should represent clear reflective expressions of the teachers' reflections. These sequences in the results section are indicative of prominent tendencies in the data material (Table 2).

\section{RESULTS}

In the following, the results will be presented in four themes: trust, courage and confidence as conditions for learning; creativity as a problem solver; synergies in subject parallels and differences as resources for joint learning.

Table 2. Phases of the analysis

\begin{tabular}{|c|c|}
\hline Analysis phase & Focus of analysis \\
\hline 1 & $\begin{array}{l}\text { Data was read several times, which led to an overall content picture of the } \\
\text { material. }\end{array}$ \\
\hline 2 & $\begin{array}{l}\text { Teachers' reflections were sorted in content groups. Similar patterns and } \\
\text { meaning units emerged. }\end{array}$ \\
\hline 3 & Final major themes were decided. \\
\hline 4 & All data was re-analysed in order to verify the patterns. \\
\hline 5 & $\begin{array}{l}\text { Selection of data that represents the teachers' reflections to be presented } \\
\text { in the paper was made. }\end{array}$ \\
\hline
\end{tabular}




\title{
Trust, courage and confidence as conditions for learning
}

The first lesson began with the teachers doing a performance for the PSTs, an "onomatopoeticmusic-drama-improvisation". The teachers wanted to perform and inspire, not just instruct, to emphasise that they are just as involved as the PSTs. The excerpt below refers to the start of the coteaching period with reference to the "onomatopoetic-music-drama-improvisation", where the teacher performance is put to the fore as well as trust and creativity as conditions for learning.

\begin{abstract}
Adam: What I learned from you two is that with strong confidence in each other's skills, we dared to try an idea [onomatopoetic-music-drama-improvisation] that was a bit unknown to the three of us, both the idea but also how we dare to frame a course for these PSTs. And also when we planned the lesson and talked about the fact that we could try this, and then we actually had to try it on the floor. So that moment when we actually acted was great fun because we were in the moment. And so I think that it is the trust and creativity you both showed, that I experienced as very strong and liberating. I think that I have learned that from you too. Then it's hard to know who does what, but both of you are in the moment, in the practice, so we can quickly change in how we can do this.
\end{abstract}

Drama teacher Adam emphasises the importance of trusting each other's competencies as a prerequisite in risking to try a new idea in your teaching, to be creative in a new situation, by changing the way in which the lesson is presented to the PSTs. To actually perform drama and music together as teachers becomes an arena for development where trust and creativity among the teachers are experienced as crucial. In terms of ZPD, Adam's development is not only guided by music teacher Charlotte's, but also by drama teacher Beatrice's way of showing trust and creativity by using her subject matter skills, where "being in the moment" shows that the referred improvisation becomes an essential arena for learning.

\section{Creativity as a problem solver}

During coteaching, problems occurred for the coteachers, as when the PSTs became unfocused when two exercises in a row were too alike. Therefore, the teachers reflected and re-planned together orally during the lesson, while the PSTs performed a drama exercise and redecided what to do next, due to student needs. The sequence below shows a conversation between the teachers during a lesson related to the described scenario.

Charlotte: It seems as they are losing focus, maybe because these two exercises were quite alike.

Beatrice: I agree. We need to think further.

Adam: Hmm (affirmative).

Charlotte: What about singing a song with them and dramatise the same, to make variation and emphasize the music together with the drama?

Adam: Let's do that.

Charlotte: Hmm, I can't think of a song that fits in today's theme. Do you know any songs that you could teach them?

Adam: I know one I think could be suitable for them but I'm not entirely comfortable with singing as that's your area of expertise. 
Charlotte: I will assist you and we can develop it together in action.

Adam: Ok let's try!

The conversation begins with a problem that the coteachers need to deal with right away during the lesson. All three coteachers agreed on the necessity to change the upcoming character of the exercise due to student reactions. The suggestion from the music teacher to sing a song and to incorporate drama into the same, is followed by drama teacher Adam acknowledging being uncomfortable singing in the presence of the more skilled music teacher. Here, he expresses singing as an arena for his ZPD. When the music teacher assures the drama teacher that she will assist him and develop the exercise with him, she expresses that she, as more knowledgeable, will help him and challenge him to go further. This indicates an important aspect, being scaffolded in one's ZPD.

In their reflections after teaching, the same situation was addressed:

Adam: These were good ideas when we planned the lesson in writing, but they turned out to be less successful in reality. So we had to make fast clarifications and changes to meet student needs. Concerning the song I taught, it didn't become prestigious although it could have had, being your competence (addressing the music teacher). I can still do it as I usually do in other situations, but here I learned more from you, just as you learned from us in the drama exercises.

Adam reflects on what occurred during the lesson, when the exercise needed to be changed in order to meet PSTs' needs. When acknowledging the music teacher's competence, this implies a description of him being in his ZPD, with the more knowledgeable other assisting him. Here, he also makes a parallel of him and his drama colleague assisting the music teacher in another situation, which is indicative of the reciprocal character of the coteaching as an arena for ZPD.

\section{Synergies in subject parallels}

Combining music and drama to "music-drama" implied merging two subject areas and exercises to form new approaches. This occurred in the exercises during the lessons and during the teachers' supervision of PSTs. There were especially synergies in subject parallels for both teachers and PSTs. Below, bold words indicate music subjects matter concepts, whereas underlined words indicate drama subject matter specific subjects.

Charlotte: We [coteachers] entered each other's dimensions and I thought that was awesome. We had different perspectives during the lessons, even when you, Beatrice, took over and gave reflections to the PSTs at the end of the day. We have different entrances, sort of, and I think that was super cool. Because I learned a lot about drama, about space, time and power. I haven't thought so much about this earlier but it is so much music in it. By working with you, I have also learned the touch points between drama and music. I think that's awesome. And even the PSTs have learned that.

Beatrice: Indeed! But the coolest thing is what we have done in our task. I think, that's because ... for them, I think, the experience is that music and drama have been merged together into something new, not that there are two different things that have just been brought together.

Music teacher Charlotte addresses different competencies among her and her coteacher colleagues, expressed as different dimensions, necessary conditions for learning in their ZPD, where a less skilled learns from a more knowledgeable other. This is related to the PSTs by referring to the lesson and to drama teacher Beatrice's reflections to the PST. When the music 
teacher become more specific, she points out which subject matter specific drama concepts she had learned from the drama teachers. Making reflections about how much music there is in the concepts from drama, synergies in subject parallels begin to occur. When she relates this experience as also being one the PSTs', Beatrice summarizes what they have learned, to perceive drama and music as intertwined. The synergy effect is shown by her saying that the PSTs have experienced the merging of music and drama as something new.

More specifically, subject matter concepts from music and drama respectively were linked together, which created new meaning and synergy effects in subject parallels:

Charlotte: These musical concepts that we used...

Adam: You mean rhythm, pulse?

Charlotte: Yes, rhythm, pulse and sound and ... tempo and dynamics, and so on.

Beatrice: So, if you put it this way: the theory comes afterwards, after experiencing the concepts in drama and music. Because it's a bit like time, space and power, they are concepts of their own and then the music concepts - but they are really the same.

Charlotte: Exactly, because I feel that power, yes, power and dynamics are quite similar.

Adam: And time and space, and time, and pulse and rhythm.

Adam: Even when we taught the PSTs these specific music concepts, I thought that I trust you all the way.

Beatrice: Let's put it this way: the theory comes afterwards, after experiencing the concepts in drama and music. Because space, and energy are specific drama concepts compared to music concepts.

Charlotte: Exactly, energy and dynamics are similar to one another.

Adam: And time and pulse and rhythm. I was thinking that when teaching the PSTs these specific music concepts, I can rely entirely on you (addressing Charlotte).

Here, the parallels between the subjects become apparent both for the teachers and the PSTs. By implementing theoretical subject specific concepts after practical exercises, they become situated in practice. Energy and dynamics are considered as parallel as well as time related to tempo, pulse and rhythm. Again, trust is emphasised in that Adam has complete confidence in Charlotte knowing musical concepts. A more skilled music teacher makes way for the drama teachers to develop more knowledge about musical concept, and vice versa, being in their ZPD. Together they create something new within the merge between the subjects. This dialogue is an expression of the coteachers describing being in their ZPD, where the teacher from the other subject has shown the way to these subject parallels. Once again, when relating to teaching the PSTs in the class, drama teacher Adam stresses his trust in music teacher Charlotte as the more knowledgeable other. Beatrice clearly addresses the relation between theory and practice, where the first comes second, which makes it possible to experience the concepts before learning them in text. Finally, Charlotte and Adam continue by mentioning even more concepts stressing their parallel meanings, that make visible synergies in subject parallels.

\section{Differences as resources for joint learning}

A significant aspect of the coteaching period was considering differences in competencies as resources for joint learning. Here, drama teacher Beatrice emphasises the combination of 
planning before and changing your planning and reflecting together during coteaching in the classroom.

Beatrice: The very presumption is that this is unpretentious but also that one can contribute with one's different competencies. It is not so important who comes up with what, but "that was a good idea" and you accept it and try it. Trusting that I do not have to do everything myself. Others also have a lot of expertise and it will be terrific although not be exactly as I imagined /. ./ What I was thinking was that it is an advantage for the PSTs to be more than one teacher supplying different encouragements, we supervise them in different ways. And there is always some instructions that appeal better to someone in the student group.

Beatrice describes the absence of prestige among the teachers that enables them to contribute with their different competencies, affirming each other's ideas. This also concerns trusting each other's competence and to "be in the moment", letting go of having control situation and trusting your colleagues in creating good teaching for the PSTs. In the ZPD, the colleague's competence make creativity and trust possible, where you learn as you go along, with guidance from the other teacher. Thus, the differences between the teachers become resources for joint learning. Beatrice describes the benefits from being more than one teacher in the classroom at once during supervising. As the teachers give different subject approaches, the PSTs have the opportunity to embrace a certain teacher's instruction more than another, giving them a larger variation than would have been offered by one teacher. Here, coteaching becomes an expression for also giving the PSTs enhanced opportunities for learning based on differences as recourses for joint learning.

\section{DISCUSSION}

In the following sections, arguments including broader contexts than the case study imply a generalisation that may be considered as ambiguous. However, it is considered important to discuss the findings in a broader international, educational perspective. Coteaching in "musicdrama" has been analysed with analytical tools within a socio-cultural perspective, where aspects of learning from 'the other' in praxis by working in a zone of proximal development (ZPD) (Levykh, 2008; Vygotsky, 1978; Wertch, 1984) has been of special interest. The analysis gave rise to the main result, synergies in subjects parallels, based on the analysis of coteachers' reflections as learning processes within their ZPD.

Coteaching in higher education has been described as a collaboration contributing synergy in the classroom (Ferguson \& Wilson, 2011). Similar to Ferguson and Wilson (2011), the present study showed that the teachers gained from each others' competencies in order to meet student needs. Coteaching has also been a way to achieve instructional synergy (Buczynski \& Sisserson, 2008). Furthermore, coteaching has been shown to provide positive synergy to enhance student learning (Chu, 2006) which relates to educational synergy and positive changes related to student learning (Embury \& Dinnesen, 2013). The present study's contribution in terms of synergy in coteaching appears in the main findings, where the synergies that occurred were more specific than in earlier studies, in their character of constituting an intercorrelation of two subjects and concerning subject parallels related to drama- and music concepts. These were intertwined in the classroom as "music-drama", as a new dimension. Unlike Chu's (2006) study, where teachers from different subjects, drama teachers and teachers in writing, could use their competencies in their own subject in order to meet student needs, the present study show that the coteachers 
developed their competencies in the other subject and therefore broadened their competence in their own subject. This is shown by their discovery of parallels between subject matter specific concepts in music and drama, resulting in synergies in subject parallels. The main findings also indicate that, when coteachers reflected upon subject specific concepts, content knowledge, pedagogical knowledge and pedagogical content knowledge (Kerin \& Murphy, 2015; Murphy \& Martin, 2015) are being developed among them. This occurred when they were practicing drama and music with their students and then reflecting about the concepts, in a practice where experience precede theoretical definitions of the concepts.

Altogether, the study shows that affective aspects; trust, courage and confidence, become prerequisites for coteachers learning in their ZPD in "music-drama". In addition, mutual creativity among the coteachers turn out to be a problem solver in the classroom, in order to adjust the teaching to better meet PST needs. Furthermore, reflections regarding how much music there is in subject matter specific concepts from drama and vice versa, with reference to the classroom practice, reveal synergies in subject parallels. Moreover, benefits from being more than one teacher in the classroom with competencies from two different subjects, drama and music, gave both PSTs and coteachers enhanced conditions for learning due to differences as recourses for joint learning.

Related to the purpose of coteaching, the present study enabled a closer connection between theory and practice (Murphy \& Martin, 2015), where parallels between specific subject matter concepts were experienced in the classroom practice and reflected upon in coteaching reflections. In comparison with Vlahopol's (2018) study, which brought together practical and theoretical parts of the student musicians, the current study merged practical and theoretical aspects of two subjects into "music-drama" resulting in a widened subject matter concept understanding among the coteachers from coteaching and reflections.

\section{CONCLUSION}

To conclude, the coteaching among the teachers in the study was characterised by collaboration and cooperation, focussing on emotional connections between them (Levykh, 2008). In line with Levykh (2008) who highlights Vygotsky's emphasize on both affect and intellect related to learning and development, affective connections between the teachers appeared to constitute both a prerequisite and a paramount aspect for wanting to develop their teaching together. The ZPD among the teachers in the study turned out to be a mutual learning process where the participants learned by interacting with each other (Tudge \& Scrimsher, 2003). The collective character of teaching and learning occurred. Hence, it is concluded that coteaching in the current study clearly indicates the importance of showing mutual respect between teachers, which relates to the collective character of teaching and learning based on sociocultural perspectives (Murphy et al., 2015; Vygotsky, 1978). An intercorrelation of drama and music in coteaching "music-drama" in an aesthetic course in preschool education gave rise to a new dimension, synergies in subject parallels. Hence, implications for aesthetic courses in preschool education promote and create conditions for teachers from different subjects to coplan, coteach and coevaluate together. This in turn can create conditions for developing further synergies between aesthetic subjects. Then, a more holistic approach that relates to PST learning and their future profession as preschool teachers can be achieved. As such, this study could point towards 21st century learning, moving towards more postmodern approaches, such as transdisciplinarity (Savage \& Drake, 2017). 


\section{ACKNOWLEDGEMENTS}

The authors declare no potential conflicts of interest with respect to the research, authorship, and/or publication of this article.

\section{ABOUT THE AUTHORS}

Marie-Helene Zimmerman Nilsson ( $\mathrm{PhD}$ in Music Education) is an associate profession in education at University West, Sweden. Her research interest comprises teacher education with special emphasis on teacher educators' and pre-service teachers' learning. Her research also focuses on higher music education and early childhood education.

Colette Murphy (BSc (Hons), MEd, MSc, PhD, MIBiol, FHEA) is a science education professor at Trinity College Dublin. She has published the key international text, a short textbook, and many research articles on coteaching. She is well known for her work on coteaching in initial teacher education, and for her expertise in Vygotsky and science learning. A Vygotsky scholar, her current research is grounded mostly in a neo-Vygotskian perspective, which focuses on learner agency.

\section{REFERENCES}

Buczynski, S., \& Sisserson, K. (2008). School district and university Co-teaching: Toward instructional synergy in an induction/M.Ed. Program. Issues in Teacher Education, 17(1), 47-74.

Chu, C. W. L. (2006). Co-teaching as a possibility for differentiated instruction. The Internet TESL Journal, 12(11). http://itesl.org/Articles/Chu-Coteaching.html.

Embury, C. D., \& Dinnesen, M. S. (2013). Co-teaching in inclusive classrooms using structured collaborative planning. Kentucky Journal of Excellence in College Teaching and Learning, 10(3), 35-52.

Ferguson, J., \& Wilson, J. C. (2011). Power and expertise in the co-taught higher education classroom. Scholar-Practitioner Quarterly, 5(1), 52-68.

Graneheim, U. H., \& Lundman, B. (2004). Qualitative content analysis in nursing research: Concepts, procedures and measures to achieve trustworthiness. Nurse Education Today, 24(2), 105-112.

Guise, M., Habib, M., Thiessen, K., \& Robbins, A. (2017). Continuum of co-teaching implementation: Moving from traditional student teaching to co-teaching. Teaching and Teacher Education, 66, 370-382.

Kadri, E., \& Salles, M. (2019). Expanding the research on interacting and power in \{coteaching|cogenerative dialogue\}: Contributions of CDA. Calidoscópio, 17(2), 320-341.

Kerin, M., \& Murphy, C. (2015). Exploring the impact of coteaching on pre-service music teachers. Asia Pacific Journal of Teacher Education, 43(4), 309-323.

Levykh, M. G. (2008). The Affective establishment and maintenance of Vygotsky's zone of proximal development. Educational Theory, 58(1), 83-101.

Locke, J., Clancy, T., Lisella, R., Rosenau, P., Ferreira, C., \& Rainsbury, J. (2017). The lived experiences of instructors Co-teaching in higher education. Brock Education Journal, 26(1), 22-35. 
McClure, G., \& Cahnmann-Taylor, M. (2010). Pushing back against push-in: ESOL teacher resistance and the complexities of coteaching. TESOL Journal, 1 (1), 101-129.

Murphy, C., \& Carlisle, K. (2008). Situating relational ontology and transformative activist stance within the everyday practice of coteaching and co-generative dialogue. Cultural Studies of Science Education, 3, 493-506.

Murphy, C., Carlisle, K., \& Beggs, J. (2009). Can they go it alone? Addressing criticism of coteaching. Cultural Studies of Science Education, 4, 461-475.

Murphy, C., \& Martin, S. (2015). Coteaching in teacher education: Research and practice. Asia-Pacific Journal of Teacher Education, 43(4), 277-280.

Murphy, C., Scantlebury, K, \& Milne, C. (2015). Using Vygotsky's zone of proximal development to propose and test an explanatory model for conceptualising coteaching in pre-service science teacher education. Asia-Pacific Journal of Teacher Education, 43(4), 281-295.

Roth, W.-M., Masciotra, \& Boyd, N. (1999). Becoming-in-the-classroom: A case-study of teacher development through coteaching. Teaching and Teacher Education, 15(7), 771-784.

Roth, W.-M., \& Tobin, K. (2005). Coteaching: From practice to theory. In W.-M. Roth, \& K. Tobin (Eds.), Teaching together learning together (pp. 5-26). New York: Peter Lang.

Savage, M., \& Drake, A. M. (2017). Living transdisciplinary curriculum: Teachers' experiences with the international baccalaureate's primary years program. International Electronical Journal of Elementary Education, 9(1), 1-20.

Scantlebury, K., Gallo-Fox, J., \& Wassell, B. (2008). Coteaching as a model for preservice secondary science teacher education. Teaching and Teacher Education, 24(4), 967-981.

Stinson, M. (2009). 'Drama is like reversing everything': Intervention research as teacher professional development. Research in Drama Education. The Journal of Applied Theatre and Performance, 14(2), 225-243.

Tudge, J. R. H., \& Scrimsher, S. (2003). Lev S. Vygotsky on education: A cultural-historical, interpersonal, and individual approach to development. In B. J. Zimmerman, \& D. H. Schunk (Eds.), Educational psychology: A century of contributions (pp. 207-228). Mahwah, NJ: Lawrence Erlbaum Associates.

Van Oers, B. (2007). In the zone. Children in Europe: Vygotsky Edition (pp. 14-15). Edinburgh: Children in Scotland.

Vlahopol, G. (2018). Possible approaches to the concept of collaborative teaching in the "music analysis" course. Benefits and challenges. Review of Artistic Education, 15, 74-83.

Vygotsky, L. S. (1978). Mind in society: The development of higher psychological processes. In M. Cole, V. John-Steiner, S. Scribner, \& E. Souberman (Eds.), Cambridge, MA: Harvard University Press.

Wertsch, J. V. (1984). The zone of proximal development. Some conceptual issues. In B. Rogoff, \& J. V. Wertsch (Eds.), Children's learning in the zone of proximal development (pp 7-18). San Fransisco: Jossey Bass.

Yin, R. K. (2009). Case study research: Design and method (4th ed.). Thousand Oaks, CA: Sage.

Open Access. This is an open-access article distributed under the terms of the Creative Commons Attribution-NonCommercial 4.0 International License (https://creativecommons.org/licenses/by-nc/4.0/), which permits unrestricted use, distribution, and reproduction in any medium for non-commercial purposes, provided the original author and source are credited, a link to the CC License is provided, and changes - if any - are indicated. 